\title{
Going by the Book: Valuation Ratios and Stock Returns
}

\author{
by \\ Ki-Soon Choi \\ M.S., Princeton University (2016) \\ B.A., Korea University (2014) \\ Submitted to the Department of Management \\ in partial fulfillment of the requirements for the degree of \\ Master of Science in Management Research \\ at the \\ MASSACHUSETTS INSTITUTE OF TECHNOLOGY \\ June 2021 \\ (C) Massachusetts Institute of Technology 2021. All rights reserved.
}

Author

Department of Management

April 15, 2021

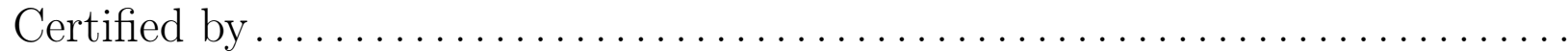

Eric C. So

Sloan Distinguished Professor of Management Thesis Supervisor

Accepted by

Catherine Tucker Sloan Distinguished Professor of Management Professor, Marketing Faculty Chair, MIT Sloan PhD Program 


\title{
Going by the Book: Valuation Ratios and Stock Returns
}

\author{
by \\ Ki-Soon Choi \\ Submitted to the Department of Management \\ on April 15, 2021, in partial fulfillment of the \\ requirements for the degree of \\ Master of Science in Management Research
}

\begin{abstract}
I explore how institutional frictions interact with the changing nature of the book value of equity to impact stock returns. I first find that book-to-market is relatively less informative of future returns when it significantly deviates from other valuation multiples, and employing refined signals improve return predictability. Then, I find that a firm's stock returns are still strongly correlated with its book-to-market portfolio returns even when book-to-market is less informative. Together, my findings suggest that institutional investors follow "brand indices" that overweight firms' book-to-market to attract capital, which induces excess correlations along the book-to-market dimension, even when book-to-market is less informative of long-term future returns.
\end{abstract}

Thesis Supervisor: Eric C. So

Title: Sloan Distinguished Professor of Management 


\section{Introduction}

I explore how institutional frictions interact with the changing nature of the book value of equity to impact stock returns. Our research question is motivated by the idea that there is a significant increase in the number of cases where the book value of equity causes the book-to-market ratio to considerably differ from other valuation multiples (e.g., negative book value); yet, there exist institutional features that induce investors to nonetheless rely on book-to-market (e.g., index-following).

I first find that book-to-market is relatively less informative of future returns when it significantly deviates from other valuation multiples, and employing refined signals improve return predictability. Then, I find that a firm's stock returns are still strongly correlated with its book-to-market portfolio returns even when book-to-market is less informative. Jointly, our findings indicate that investors excessively trade based on the book-to-market ratio when it is suboptimal to do so, which in turn causes a firm's returns to co-move too much with that of its book-to-market peers. I shed light on the importance of understanding how institutional frictions shape investor behavior, and how they interact with the changing nature of accounting information to affect prices.

I focus on book-to-market as it is one of the most widely used accounting-based signals, studied by both academics and practitioners. In the academic literature, book-to-market is considered as a key ingredient in standard asset pricing models, either as a risk factor or a signal of mispricing ([15], [20], among others). In practice, Russell Value and Growth indices assign more than 50\% of weight in the book-to-market factor in defining a stock as value or growth $^{1}([14])$, and mutual funds often offer value portfolios that primarily classify stocks on the book-to-market ratio. ${ }^{2}$ Across the industry, long-short strategies based on book-tomarket have gained popularity as to become a widespread "investing style" ([17]). In this sense, our study relates to the literature in style investing, such as [2] identifying a model of excess comovements of assets within styles, and [35] documenting the predictability of past style returns based on size and book-to-market.

\footnotetext{
${ }^{1}$ https://www.ftse.com/products/downloads/Russell-US-indexes.pdf

${ }^{2}$ DFA US Targeted Value Portfolio Prospectus, https://us.dimensional.com/funds/us-targeted-value
} 
Although prior research heavily relies upon book-to-market (and thus the book value of equity) in explaining the cross-section of stock returns ([29], [8], [15]), the evolution of the modern economy may affect the way book values reflect the residual values to shareholders. Manufacturing, which contributed around $25 \%$ of value-added as a percentage of GDP in 1950s, has now fallen to $11 \%$, whereas value-added by nontraditional sectors of professional and business services increased from $3.5 \%$ to $12 \%{ }^{3}$ While disruptive technologies have transformed how firms operate and generate profit, the book value of equity has been slower in reflecting these changes, such as the expensing of research and development (R\&D) and advertising activities failing to capture potential intellectual and brand assets. Industry and media reports are also starting to recognize that book values may fail to capture appropriate value stocks, documenting the existence of "veiled value stocks" ([14]) and suggesting that "the traditional way of measuring value may be history." ([18])

A more recent trend of large amounts of share repurchases may also contribute to the problem. ${ }^{4}$ Consider the case of H\&R Block, which reported the book value of equity of $\$ 23$ million and market capitalization of $\$ 4.8$ billion in FY2015, resulting the firm to be in the bottom $5 \%$ in the entire cross-section of firms with the book-to-market ratio of 0.005 . However, this low ratio can potentially be attributed to the company's $\$ 2$ billion stock buybacks, a part of the firm's decision to repurchase $\$ 3.5$ billion worth of shares until 2019 . While book-to-market places H\&R Block as a glamour stock, other valuation ratios suggest otherwise; according to its earnings-to-price, EBITDA/EV, and shareholder yield, the firm is ranked around top 15\% of cheap stocks, indicating it as a value stock. Combined with this trend that drastically reduces the book value of equity, the cases where the book-to-market signal deviates from other indicators of firm's cheapness are becoming more frequent and economically significant ([14], [18]).

While some investors may recognize and adjust the potentially misleading book-to-market signal, there also exist investors who still rely on it for various reasons. First, well-known indices such as Russell Value/Growth hold a long-standing tradition of using book-to-market in classifying value stocks. As institutional investors often benchmark their products to the

\footnotetext{
${ }^{3}$ Bureau of Economic Analysis, https://www.bea.gov/industry/gdpbyind_data.htm

${ }^{4}$ According to a report by Goldman Sachs Global Investment Research, S\&P 500 companies are projected to authorize a record of $\$ 1$ trillion in stock buybacks in 2018. [11]
} 
"brand indices" to attract capital, they inevitably follow book-to-market. Second, fully internalizing the changing implications is costly for both indices and institutions. Adopting new valuation metrics require thorough research and back-testing, and switching from an existing signal creates discontinuity in performance tracking. Institutions also take caution in changing their past investment approaches to avoid legal consequences, especially when there are not many others to share the blame. Therefore, for those institutions where the costs may outweigh the benefits, they are likely to continue pursuing book-to-market strategies. Lastly, there may also exist investors who lack the knowledge to systematically adjust the book value of equity.

I conjecture that these frictions induce excess correlations along the book-to-market dimension, even when book-to-market is less informative of long-term future returns. As investors systematically maintain their book-to-market portfolio, demands of the stocks in the same group move in concert. This is consistent with [3], who find that fund flows chasing S\&P 500 raise correlations of the included stock's returns with that of other S\&P stocks. For instance, H\&R Block, which reasonably seems to be a value stock along the other ratios, will be traded as a glamour stock by the book-to-market followers. Therefore, its prices are affected by the same fund flows that sell book-to-market glamour stocks, causing its returns to move in tandem with other book-to-market glamour stocks' returns, although that arguably should not be the case based on the other signals.

Moreover, because the classification of "value" and "growth" is most strongly identified in the extreme ranking groups, the larger discrepancy between the signals causes the bookto-market strategies to trade the stock in the opposite direction of what other valuation multiples indicate. Assuming that these other metrics provide a better approximation of a firm's cheapness, the book-to-market strategies allocate more capital to work against the direction originally intended by optimal value strategies. In this sense, I define the stock to be "excessively" traded based on the book-to-market signal if a firm's returns are more correlated with the returns of its book-to-market peers relative to the peers based on other measures, even when it is less informative of future returns.

To gauge how much book-to-market differs from other indicators of value, I employ two benchmark measures. First, I use the retained earnings-to-market ratio to alleviate 
the noise added by the contributed capital component of the book value of equity ([1]). Second, I follow [14] to combine other indicators commonly used in practice (e.g., earningsto-price, cash flow-to-price, shareholder yield) into a single factor, called the "composite signal" (or composite score). (See Appendix A for details.) The purpose of the composite signal is to provide a more complete picture of a firm's cheapness by considering multiple dimensions of the firm's performance that would improve returns to value strategies. ${ }^{5}$ I use the term "alternative signals" to refer to the retained earnings-to-market ratio and/or the composite signal throughout the paper. Next, I compute the "ranking difference," which is the absolute difference between the firm's book-to-market quintile ranking and the alternativesignal quintile ranking. The larger the ranking difference, the stronger the book-to-market signal classifies a stock in the opposite direction of the alternative signals.

I show how investors trade excessively along the book-to-market dimension by conducting two main tests. First, I validate the retained earnings-to-market ratio and the composite signal as better approximations of cheapness compared to the book-to-market ratio. I find that sorting based on the alternative signals have stronger return predictability relative to book-to-market as the ranking difference widens. Second, I test whether individual stock returns become more correlated with returns of its corresponding book-to-market portfolio compared to the retained earnings-to-market (or the composite) portfolio as the ranking difference widens.

Our second test is motivated by the idea that as the discrepancy between the two signals becomes severe, book-to-market strategies will more likely trade in the opposite direction of what the alternative signals suggest. For instance, small values of ranking difference indicate that the two signals align, taking the same side of the trade; in contrast, large values of ranking difference imply that the stock is classified as a strong value using one signal and a strong glamour in the other, resulting in trades that oppose each other. Therefore, investors who trade on book-to-market end up allocating larger amounts of capital that pushes against the alternative signals when the difference is large. Although optimal value strategies would trade stocks based on the alternative signals and thus yield correlations among the composite

\footnotetext{
${ }^{5}$ I acknowledge that I can never identify a firm's true cheapness, if there is any. This measure aims to provide a potential benchmark that value strategies should consider when comparing a firm's current and expected value.
} 
peers, the opposing force hampers this trajectory due to the correlations created along the book-to-market dimension. Consistent with this prediction, I find that contemporaneously, the ranking difference is positively correlated with how much a firm's returns covary with its corresponding book-to-market portfolio relative to the composite portfolio. Together, these tests suggest that there exist investors who heavily trade stocks based on book-to-market, even though it is inferior to do so in implementing value strategies.

Moving forward, I hope to conduct additional tests to validate our conjecture and study other market consequences. First, along with the items mentioned previously, I plan to verify additional sources of distortions and their prevalence in a large-sample setting, such as stock compensation, order backlog, deferred revenues, and those mentioned in [13], which are not captured by the book value of equity and may contribute to deviations from the alternative signals. Second, I plan to look at the shorter-term market reactions during information events (e.g., earnings announcements) to test other implications, such as the mechanical trading on book-to-market offsetting price reactions of other signals and slowing down price discovery. Third, I hope to conduct cross-sectional tests based on variation in the capital employed by quasi-index value funds to examine whether the excess correlation becomes stronger in stocks with more index-chasing funds.

In sum, I explore the implications of evolving book values and institutional frictions on stock returns. I hope to contribute to the literature in three ways. First, I add to the understanding of the mapping of accounting information into market prices (and by extension to firm's cost of capital) by incorporating market frictions. Second, I provide a platform in evaluating the potential implications of accounting rules on market outcomes. While the current working paper cannot pinpoint the cause of the discrepancy and excess trading to solely the accounting rules (e.g., expensing of R\&D as opposed to capitalizing), I hope it can provide a conceptual framework of how accounting rules potentially can affect market outcomes. Lastly, this research sheds light on the importance of institutional frictions on the efficacy of fundamental analysis. While accounting information is the root of fundamental analysis, investing entities use different methodologies in applying it due to various frictions, which ultimately shape the returns to value investing in an unexpected manner.

The remainder of the paper proceeds as follows: Section 2 reviews prior literature and 
presents the main hypotheses. Section 3 describes the data and methodology used to construct key variables. Empirical results are discussed in Section 4, and Section 5 concludes.

\section{Background and Hypothesis Development}

\subsection{Book-to-Market and Expected Returns}

While there is a long-standing literature exploring the relationship between book-tomarket and expected returns, ${ }^{6}$ further research explores the imperfection of book-to-market in the context of accounting. [22] find that correcting book-to-market for the conservatism factor provides greater explanatory power in predicting future investments, and other works have constructed various measures, such as G-Score and F-Score, to strengthen return predictability in subsets of book-to-market portfolio groups ([23], [27]). [9] suggest the possibility that failing to adjust book-to-market or earnings-to-market for the long-term benefits of R\&D may lead to severe mispricing, although they do not find a direct link between R\&D spending and future returns. Recent work by [1] decomposes the book value of equity into two parts, and finds that the predictive power of book-to-market comes from retained earnings, not contributed capital.

Other works also examine whether the evolution of the economy affects the value-relevance of accounting information in general. [21] claim the "end of accounting" by suggesting that the value-relevance of earnings and book values have declined. On the other hand, [4] argue that other accounting amounts that reflect firms' intangible assets, growth opportunities, and alternative performance measures have increased in value-relevance. Without taking a stance on whether value-relevance of accounting amounts has decreased or not, this paper studies how the changing nature of accounting representation maps into prices, where market participants often use the information as a stationary input. In this context, I explore the impact of institutional frictions of implementing book-to-market strategies and how they affect market dynamics.

\footnotetext{
${ }^{6}$ See for example, [28], [25], [29], [8], [15], [20], [26], [34], [36], and [7]
} 


\subsection{Institutional Frictions and Investor Behavior}

Classic asset pricing research often studies returns in the broad cross-section without specifying various investors types. However, in reality, arbitrage is typically pursued by specialized traders who face different frictions and engage in specific strategies. While there are some investors who adjust book values to better reflect value, there are also those that do not for institutional or behavioral reasons. A notable example of the latter group is index-followers. Indices such as Russell Value or Growth still incorporate book-to-market considerably in classifying value or glamour stocks. Therefore, those institutions who offer index-benchmarked products for various reasons, such as popularity, end up trading on bookto-market ratios. Similar logic applies to funds pursuing book-to-market strategies in general. Considering the cost of changing and justifying their revised investment thesis, institutions may find it worthwhile to maintain the status quo.

This type of path-dependent investment behavior, where investors continue to follow potentially misleading signals, is consistent with prior models where managers rely upon resource-providers for the assets they manage, also known as the separation of "brain" and "resources." As arbitrageurs are evaluated by the resource-providers based on the performance in a given time span, arbitrage becomes risky ([32]). [6] empirically document the existence of hedge funds who chose to "ride the bubble" instead of betting against it during the period of IT boom. Institutional investors' decision to follow indices that employ bookto-market is also consistent with models of managers' reputation concerns ([30]) and theories of informational cascades, where they understand that their private signals are imprecise and thus rationally mimic the behavior of others. ([5]).

Our study relates to the literature in style investing, where investors systematically categorize and allocate funds to "styles" rather than individual securities. Style investing has become popular particularly among institutional investors, who often times must follow systematic trading rules as fiduciaries. The capacity to process large amount of information reasonably well ([24]) and easier performance evaluation ([31]) contribute to why style investing has become attractive, and now fund managers frequently advertise themselves as pursuing a particular style. Consistently, prior research shows that institutional investors re- 
allocate their portfolios across style groupings more than across random stock groups ([16]), and investors' portfolio decisions are affected by style categorizations ([19]). In turn, number of studies look at the potential consequences of book-to-market strategies in stock returns, such as excess return comovements within styles and the predictive power of past style returns $([2],[35])$.

\subsection{Hypotheses}

As non-trivial amount of investors rationally refrain from deviating from the popular yet possibly misleading signal, I conjecture that in the short run, a stock becomes excessively traded along the book-to-market dimension relative to what is suggested by the alternative signals. However, one may argue that the strong correlation along the book-to-market dimension exists because the firm's cheapness is indeed similar to firms in the same book-to-market portfolio. To explore this alternative explanation, I test the first hypothesis:

H1: The greater the difference between book-to-market and the alternative signals (retained earnings-to-market or the composite), the more improved long-term returns become when employing the alternative signals.

The first test is motivated by the idea that if book-to-market accurately classifies a stock as value or glamour, it should positively predict returns for stocks with large discrepancies, and should work as least as well compared to the alternative signals, if not better. $H 1$ also implies that in the long term, those investors who internalize the implications of book values to their strategies earn higher returns when the two signals are misaligned. Moving forward, I are also working on constructing another signal focusing on accounting rules that potentially introduce noise in book values, such as the treatment of goodwill, R\&D, advertising expense, and intangible investments in SG\&A. However, the current results are also meaningful in documenting the path-dependent investment behavior even though there are rooms for improvement.

As the alternative signals attempt to provide a more complete picture of cheapness for optimal value strategies, the extent to which a stock is being excessively traded depends on how much book-to-market contrasts with the alternative signals. If the two signals align, then book-to-market also similarly reflects the cheapness of the stock, so the stock would 
be traded with its appropriate peers. However, if book-to-market classifies the stock in the opposite direction of the alternative, it is more likely to be traded with its book-to-market peers instead of those with similar alternative signals. This brings to our second hypothesis:

H2: The greater the difference between book-to-market and the alternative signals (retained earnings-to-market or the composite), the more a stock's returns covary with returns of its book-to-market peers, compared to returns of peers based on the alternative signals.

H2 implies that as the two signals become more dissimilar, the stock becomes traded more like a book-to-market glamour (value) stock, although the other measure indicate value (glamour). H2 also implicitly tests the existence of institutional frictions. If institutional investors do not face the aforementioned frictions, they should be able to flexibly adjust their strategies by employing improved signals to achieve higher future returns. This would result in a firm's stock returns to be more positively correlated with its retained earnings-to-market or composite portfolio returns when the discrepancy between the two signals is severe.

\section{Data and Variable Construction}

I construct the sample by taking the financial statement data from Compustat and the price and return data from CRSP. I first take ordinary common stocks that are traded on NYSE, Amex, and NASDAQ. Following [12], I exclude financial firms and firms with share price less than $\$ 5$. I require the stock to have past 12 -month returns and adjust for delisting returns following [33]. The final sample consists of 105,380 firm-years from 1975 to 2016.

I measure how different book-to-market is from other valuation multiples by constructing variables "retained earnings-to-market," "composite score," and "ranking difference." I follow [1] to compute the retained earnings-to-market ratio, defined as retained earnings less accumulated other comprehensive income, divided by the market value of equity. In constructing the composite score, I first compute percentile rankings of firms based on five other valuation multiples that may portray value: earnings-to-price, sales-to-price, cash flow-to-price, earnings before interest, depreciation, and amortization-to-enterprise value (EBITDA/EV), and shareholder yield. Then, I sum each metric's percentile rankings to create the composite 
score, and finally create quintile rankings based on the composite score. ${ }^{7}$ I use NYSE breakpoints in sorting the firms into quintiles with respect to each signal (i.e., book-to-market, retained earnings-to-market, and composite). The ranking difference equals the absolute difference between the quintile rankings of the two measures. For example, if the two signals exactly align, the ranking difference equals zero, and if they rank exactly in the opposite direction the ranking difference equals 4 .

Next, for each stock $i$, I calculate the corresponding market-adjusted annual book-tomarket, retained earnings-to-market, and composite portfolio returns. I allow a six-month lag between the financial statement and portfolio formation dates. Portfolios are formed on June of year $t$, and the stock itself is excluded to avoid mechanical correlation between the stock and its corresponding style portfolio ([35]). Various valuation ratios are computed using the financial statement data in the last fiscal year-end in $t-1$ and the market value of equity at the end of December of year $t-1$.

Descriptive statistics are shown in Table 1 and the time-series trend of firms with large ranking difference are shown in Figure 2. Panels B and C from Table 1 and Panels B and D from Figure 2 indicate that the cases of large ranking difference between book-to-market and the alternative signals have been increasing since the 1990s, both by the number of firms and market capitalization. This is consistent with the evolution of the economy characterized by large investments in intangible assets not capitalized on the balance sheet and/or share repurchases.

Table 2 reports the correlations between book-to-market and other valuation multiples. Panel A presents the correlations among various valuation multiples. I observe that bookto-market is most weakly positively correlated with shareholder yield, earnings-to-price, and EBITDA/EV. Also, book-to-market seems to be more correlated with retained earningsto-market than with the composite score, possibly due to the mechanical linear relation between book values and retained earnings. Panel B presents the correlations of book-tomarket with other multiples by sub-periods. I observe that book-to-market's correlation with other valuation metrics have generally dropped since the 1990s, which is consistent with the

\footnotetext{
${ }^{7} \mathrm{I}$ acknowledge that this method was inspired by the multi-factor approach devised by James O'Shaughnessy: https://www.valuesignals.com/Screens/Details/OShaughnessy_Trending_Value.
} 
trend of increasing deviation of book-to-market.

Table 3 reports the equal-weighted annual portfolio returns based on book-to-market, retained earnings-to-market, and the composite. I observe that long-short strategies based on the retained earnings-to-market ratio (composite signal) outperforms those based on bookto-market by approximately 1.1 (5.0) percentage points annually, with higher t-statistics.

\section{Empirical Models and Results}

This section presents the empirical set-up and results of the main tests. I first test whether long-term returns are significantly improved when alternative signals are used relative to the book-to-market ratio. Then, I test whether a firm's returns become excessively correlated with its book-to-market portfolio as the ranking difference widens.

\subsection{Long-term Returns (H1)}

First, to explore the concern that the correlation between the firm's stock returns and its book-to-market portfolio is not "excessive," I conduct annual market-adjusted return prediction tests to show that book-to-market is inferior to the alternative signals in implementing value strategies. Assuming that investors can flexibly adjust their strategies without any frictions, if investors follow book-to-market despite the large discrepancy with the alternatives, it should be the case that strategies based on book-to-market should be at least as good as those based on the alternatives, if not better. Formally, I estimate the following Fama-MacBeth regressions:

$$
\begin{aligned}
& \operatorname{Ret}_{i, t+1}=\alpha+\beta_{1} B / M \operatorname{Rank}_{i, t}+\beta_{2} \operatorname{RankDiff}_{i, t}+\beta_{3} B / M \text { Rank }_{i, t} \times \text { RankDiff }_{i, t}+\text { Controls } \\
& \operatorname{Ret}_{i, t+1}=\alpha+\beta_{1} R / M \operatorname{Rank}_{i, t}+\beta_{2} \operatorname{RankDiff}_{i, t}+\beta_{3} R / M \text { Rank }_{i, t} \times \text { RankDiff }_{i, t}+\text { Controls } \\
& \operatorname{Ret}_{i, t+1}=\alpha+\beta_{1} \text { COMP } \operatorname{Rank}_{i, t}+\beta_{2} \operatorname{RankDiff}_{i, t}+\beta_{3} \text { COMP Rank }_{i, t} \times \text { RankDiff }_{i, t}+\text { Controls }
\end{aligned}
$$

The dependent variable $\operatorname{Ret}_{i, t+1}$ refers to firm $i$ 's 12-month future returns after the portfo-

lio formation date at year $t . B / M, R / M$, Composite Rank refer to the quintile rankings of the firm based on book-to-market, retained earnings-to-market, and the composite, respectively. RankDiff denotes the absolute difference between the quintile rankings of book-to-market 
and the alternatives. Note that Eq. (1) will be estimated twice, one using the ranking difference between book-to-market and retained earnings-to-market, and the other using the ranking difference between book-to-market and the composite. Our coefficient of interest is $\beta_{3}$, which measures how the predictability of each signal changes by the ranking difference. I include size and the past 12-month returns to control for other factors that may affect future returns.

Table 4 presents the average coefficients, $\mathrm{R}^{2} \mathrm{~s}$, and Fama-MacBeth t-statistics from the annual cross-sectional estimations of Eq. (1) and (2). Columns (1) and (2) compare the return predictability between book-to-market and retained earnings-to-market as the ranking difference changes. I observe that the interaction term in Column (1) is negative and significant, indicating that the predictability of book-to-market deteriorates as the ranking difference widens. Specifically, for firms with RankDiff $=4$, book-to-market even starts to be negatively correlated with future returns, as the combined coefficient becomes negative $(0.0217-0.01110 \times 4=-0.0223)$. On the other hand, the effects of large discrepancy are much less pronounced for firms evaluated on retained earnings-to-market, as the coefficient on $R / M$ Rank $\times$ RankDiff is weakly significant and much smaller in magnitude. Column (3) includes both book-to-market and retained earnings-to-market, where I find that retained earnings-to-market subsumes the predictability of book-to-market.

Columns (4), (5), and (6) report the equivalent analysis using book-to-market and the composite. Again, I find that book-to-market's predictability significantly deteriorates when the ranking difference widens compared to the composite. On the other hand, the composite is less affected by the ranking difference, and subsumes book-to-market when I include both signals. I validate our first hypothesis by documenting improved return predictability using alternative signals.

\subsection{Excess Correlation (H2)}

Next, to measure how much a firm's returns covary more with that of its book-to-market peers or alternative-signal peers as a function of the discrepancy, I take two approaches. First,

I first calculate the firm's corresponding portfolio returns based on book-to-market and the 
alternative signals each year. Then, I take the difference of the two monthly portfolio returns to construct the variable RetDiff:

$$
\begin{gathered}
\operatorname{RetDiff}_{i, m, t}=B / M \text { Portfolio Return }{ }_{i, m, t}-R / M \text { Portfolio Return }_{i, m, t} \\
{\text { RetDif } f_{i, m, t}=B / M \text { Portfolio Return }_{i, m, t}-\text { COMP Portfolio Return }}_{i, m, t}
\end{gathered}
$$

This return difference serves to capture the part of the book-to-market portfolio returns in excess to the alternative-signal portfolio. The idea is that as the ranking difference widens, the return component specific to the book-to-market portfolio will covary more with the firm's returns. I formally test this idea through the following regression:

$$
\operatorname{Ret}_{i, m, t}=\beta_{1} \operatorname{RetDif} f_{i, m, t}+\beta_{2} \operatorname{RankDiff}_{i, t}+\beta_{3} \operatorname{RankDiff}_{i, t} \times \operatorname{RetDiff_{i,m,t}}+\text { Controls }
$$

The dependent variable $\operatorname{Ret}_{i, m, t}$ refers to firm $i$ 's monthly returns on month $m$ at year $t$. Our coefficient of interest is the interaction term $\beta_{3}$, which captures the change in the correlation structure between individual stock returns and its corresponding portfolio peers as the ranking difference varies.

Table 5 presents the results for Eq. (4). I find that the coefficient on $\operatorname{RetDiff}\left(\beta_{1}\right)$ is negative and significant, implying that on average, individual returns are more correlated with that of its alternative-signal peers relative to its book-to-market peers. This is likely to be the case since the two signals essentially point toward the same picture, so the prediction of the book-to-market signal is subsumed by the alternative measure which has less noise. The interaction term between RankDiff and RetDiff $\left(\beta_{3}\right)$ is positive and significant. The results suggest that as the ranking difference widens, there exist excess returns in the bookto-market portfolio (which is not attributable to the alternative portfolio) that is positively correlated with the individual stock's returns. Specifically, for the largest ranking difference group (RankDiff $=4)$, a 1 percentage point increase in the difference between book-tomarket portfolio and the retained earnings-to-market (composite) portfolio is associated with 0.19 (0.03) percentage point increase in an individual firm's returns. ${ }^{8}$

As a second approach, I test whether the annual excess correlation along the book-to-

${ }^{8} 0.1823^{*} 4-0.5371=0.19,0.1392 * 4-0.5329=0.03$ 
market portfolio is positively associated with the ranking difference. To proxy for a firm's excess correlation relative to the alternative portfolio, I define the variable CorrDiff as:

$$
\operatorname{CorrDiff}_{i, t}=\rho_{t}\left(\operatorname{Ret}_{i, m}, B / M \operatorname{Ret}_{i, m}\right)-\rho_{t}\left(\operatorname{Ret}_{i, m}, R / M_{i, m} \operatorname{or} \operatorname{COMP} \operatorname{Ret}_{i, m}\right)
$$

where $\rho\left(\operatorname{Ret}_{i, m}, B / M \operatorname{Ret}_{i, m}\right), \rho\left(\operatorname{Ret}_{i, m}, R / M \operatorname{Ret}_{i, m}\right)$, and $\rho\left(\operatorname{Ret}_{i, m}, C O M P \operatorname{Ret}_{i, m}\right)$ refer to the 12-month correlation between a firm's monthly returns and its corresponding bookto-market, retained earnings-to-market, and composite portfolio returns, respectively. This variable serves to capture how much more the firm's returns covary with returns of its bookto-market peers relative to its alternative-signal peers. I then test the following specification:

$$
\text { CorrDiff } f_{i, t}=\beta_{1} \text { RankDiff } f_{i, t}+\text { Controls }
$$

Table 6 Panel A presents the results for Eq. (5). The results suggest that as the ranking difference widens by 1 unit, a firm's correlation with its book-to-market portfolio increases by 0.021 (0.006) relative to the correlation with the retained earnings-to-market (composite) portfolio. While the magnitude itself may seem small, I note that our horizon is over the course of 12 months, and the mean CorrDiff value is close to zero. I also believe that this effect will be amplified in the short-run, such as days around information events, and plan to conduct further tests in this direction.

Taken together, while book-to-market is relative less informative of future returns, I find that individual stock returns contemporaneously start to behave more similarly to its book-to-market peers as the ranking difference widens. I interpret this result as preliminary evidence of forces working in the opposite direction of the alternative signals due to the presence of investors trading on book-to-market. As book-to-market starts to significantly deviate from the alternative signals, the capital allocated to book-to-market-based strategies starts to push against those applied to the alternative signals, causing the firm's returns to co-move less with its alternative-signal peers.

I plan to corroborate our findings in the future by conducting several additional tests. First, I hope to formally validate that these deviations are driven by firms increasingly engaging in activities that create noise in the book value of equity. Specifically, I plan to 
regress the RankDiff variable on potential sources of distortions, such as R\&D, advertising, stock option expenses, and buybacks, among others. Second, I hope to look at shorterterm consequences by exploring market reactions during information events (e.g., earnings announcements). To the extent that a firm's returns are contemporaneously correlated with that of its book-to-market peers, our story suggests predictable deviations from the alternative signals in the short-run, which will subsequently reverse. As a rudimentary exercise that shares our spirit, I repeat Eq. (5) using monthly returns of shorter horizons. The results, presented in Table 6 Panel B, show that the coefficients on RankDiff increase as the time horizon is shorter following the portfolio formation. I interpret this as preliminary evidence that the excess correlation phenomenon is likely to be stronger in a relatively short time period. Third, I plan to examine whether these effects are more pronounced at times of larger capital inflows to value-chasing funds. One possible specification is to follow [10] to measure the fund flows at the mutual fund level, and test whether book-to-market investing (or passive) funds are driving our results.

\section{Conclusion}

My study explores how book values and institutional frictions jointly affect stock returns, motivated by the observation that firms in the modern economy increasingly engage in activities that may weaken book-to-market as a signal of value. Despite the changing nature of the book value of equity, there exist investors who still heavily rely on book-to-market due to frictions that cause the adjustment process to be costly. I examine the consequences of such path-dependent behavior by first providing evidence that such trading behavior is suboptimal in implementing value strategies, and entities such as indices or institutional investors can improve returns by employing other signals that consider multiple dimensions in reflecting a firm's cheapness. Next, I document the existence of excess co-movement of a firm's returns with its book-to-market portfolio relative to the alternative-signal portfolio, which becomes more pronounced as the discrepancy between the signals widens. I hope to corroborate these findings by conducting additional tests in the future.

This paper hopes to contribute to the literature in three ways. First, our results aim 
to deepen the understanding of how accounting information incorporates into prices (and by extension to the cost of capital) under market frictions. Second, I hope this paper can provide a platform in thinking about how changes to accounting rules can potentially influence market outcomes. Although the current set of tests cannot pinpoint to accounting rules as the main driver of these phenomena, it can provide a conceptual framework on assessing market impact of accounting treatments on certain items such as goodwill, R\&D, or advertising expense. Lastly, this paper contributes to the research on fundamental analysis by highlighting the role of institutional frictions in shaping the returns to value investing. As frictions cause investors to employ different methodologies in evaluating cheapness, this may affect the effectiveness of the fundamental analysis. 


\section{Figure 1. Correlation Trend}

This figure plots the yearly correlation of BM with other multiples, namely sales-to-price, gross profit-to-price, shareholder yield, and the composite.

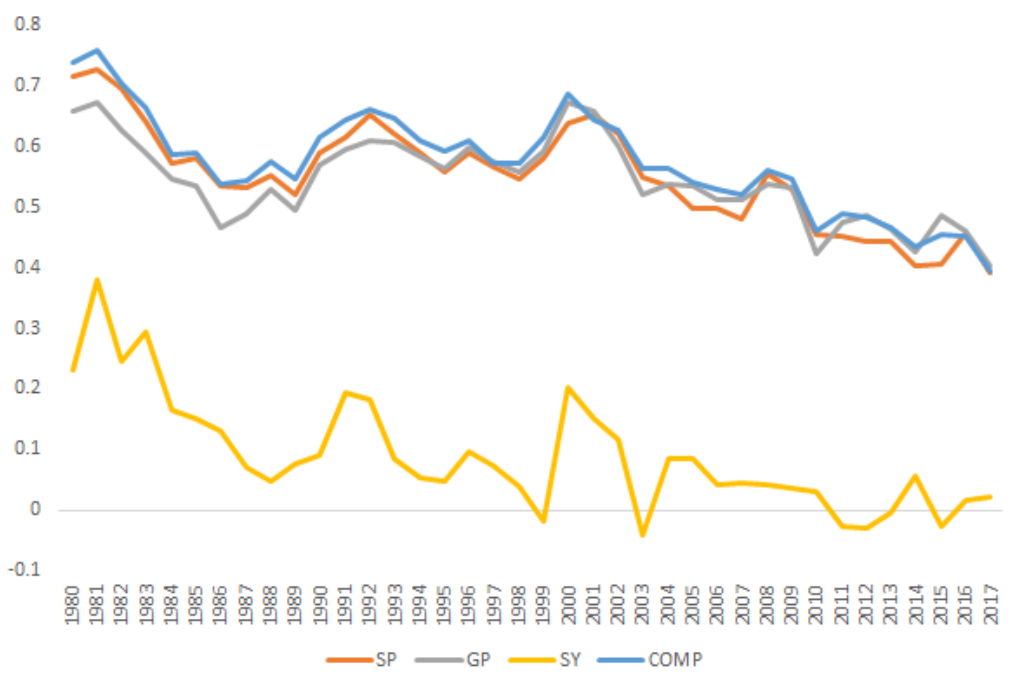




\section{Figure 2. Time Series Trend of Firms by Ranking Difference}

This figure plots the yearly market capitalization of firms by Ranking Difference. Ranking Difference (RankDiff) is the absolute difference between a firm's quintile ranking based on book-to-market and quintile ranking based on the composite. Panel A plots the time-series trend for all ranking difference groups. Panel B plots the time-series trend for large ranking difference $(>=2)$ groups. Refer to Appendix A for variables definitions.

Panel A: Yearly Trend of Firms by Ranking Difference (BM vs. COMP)
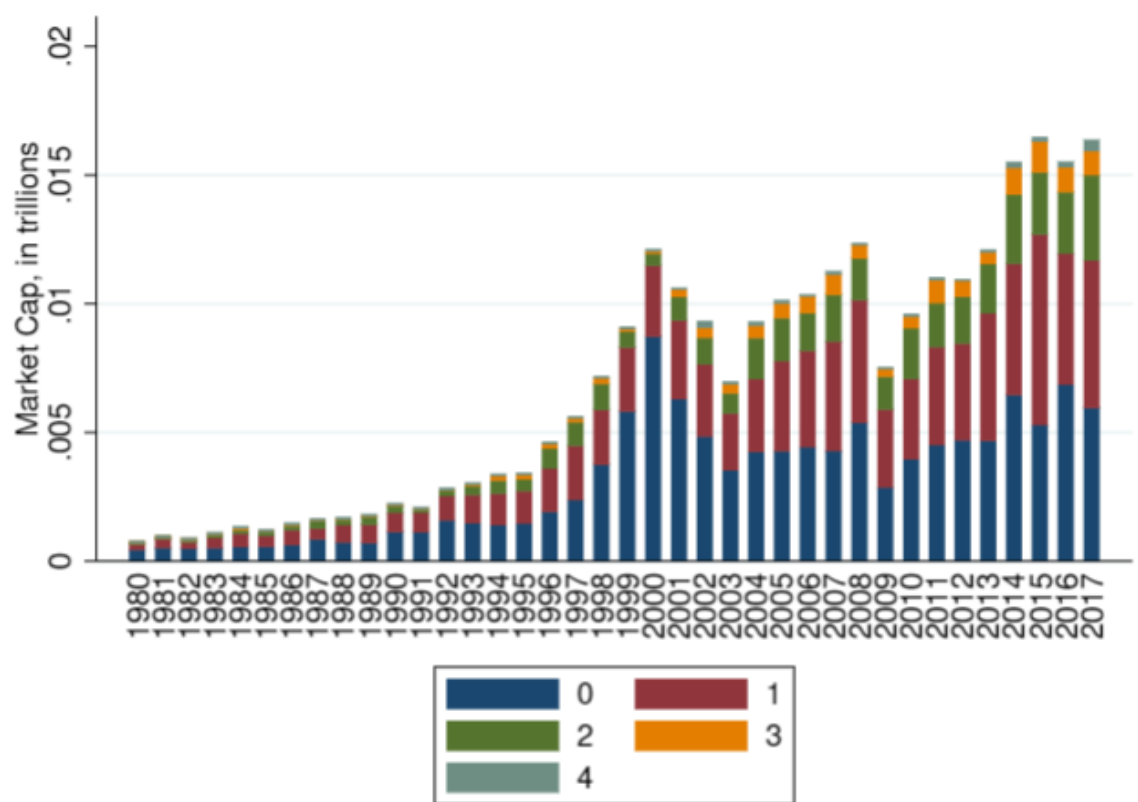

Panel B: Firms with High |RankDiff| (BM vs. COMP)

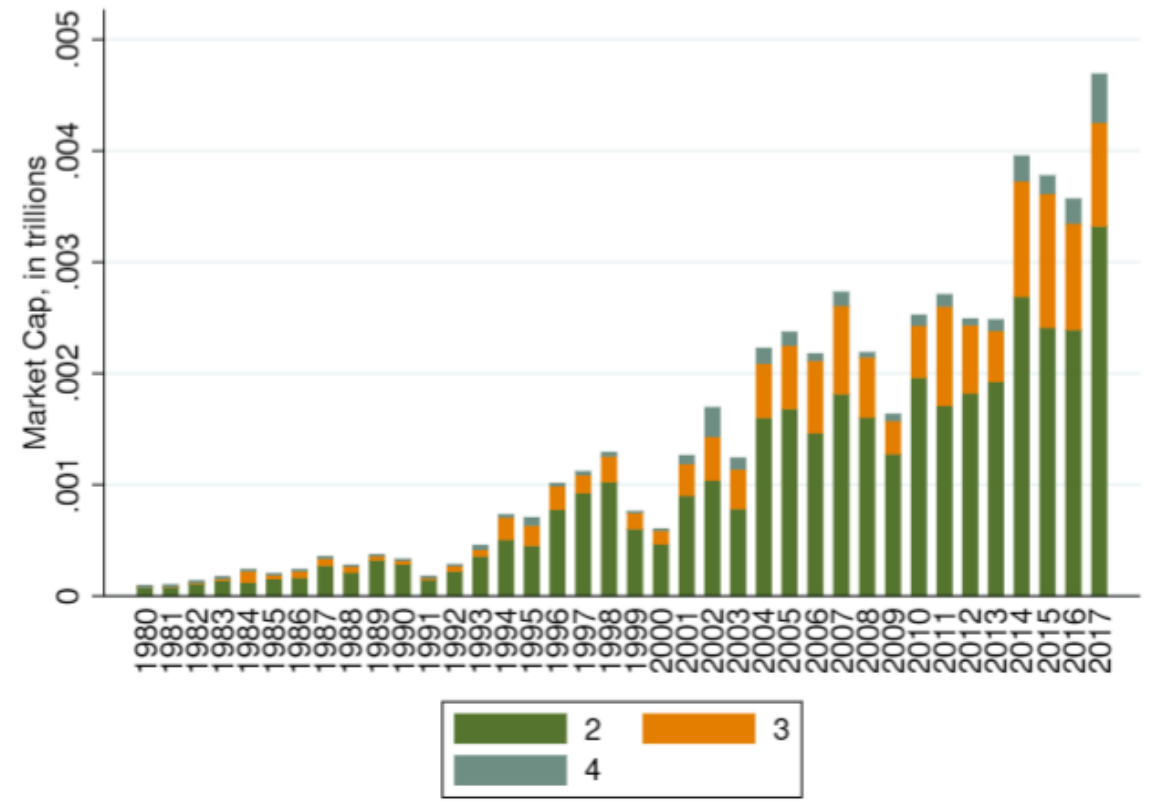




\section{Figure 3. Annual Returns to Various Long-Short Strategies}

This figure plots the market-adjusted returns to value strategies based on book-to-market and the composite. Strategies are formed by taking a long position in the top quintile and short position in the bottom quintile based on respective valuation signals at the end of June in year $t$.

Panel A: Long-Short Strategy Returns for Full Sample

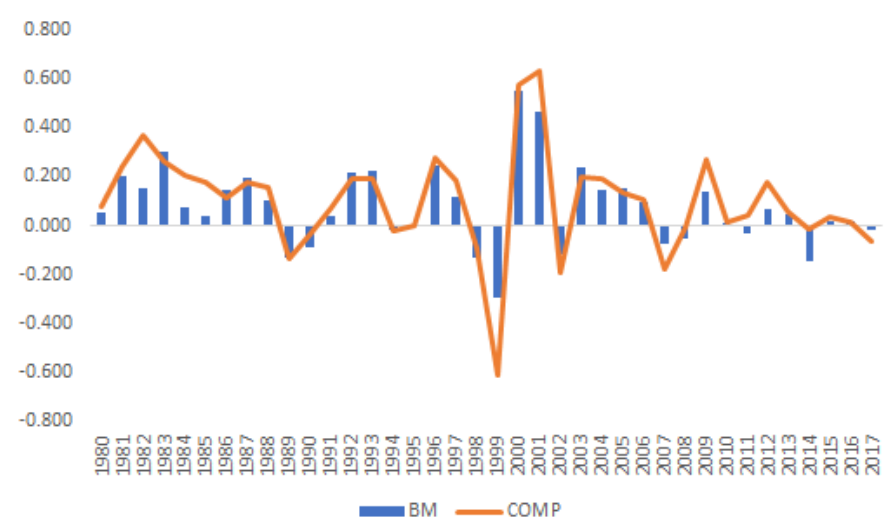

Panel B: Long-Short Strategy Returns for Low |RankDiff| Group $(<=1)$

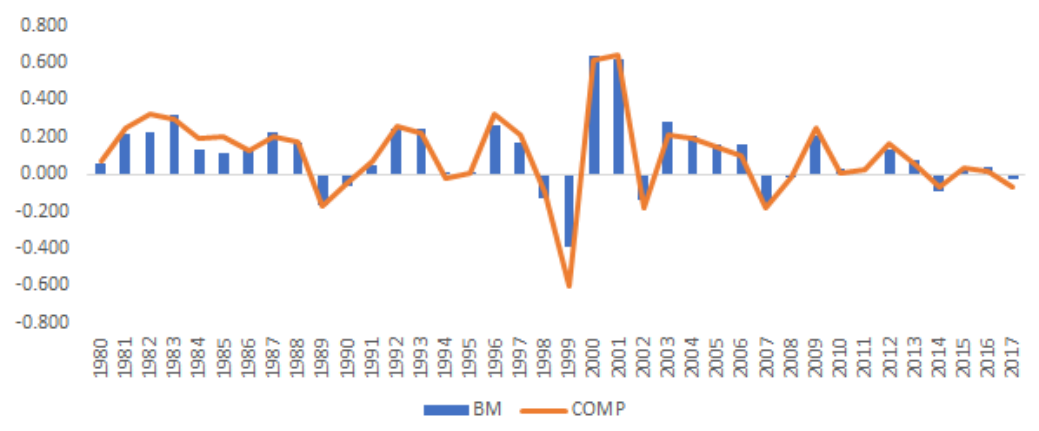

Panel C: Long-Short Strategy Returns for High |RankDiff| Group $(>=2)$

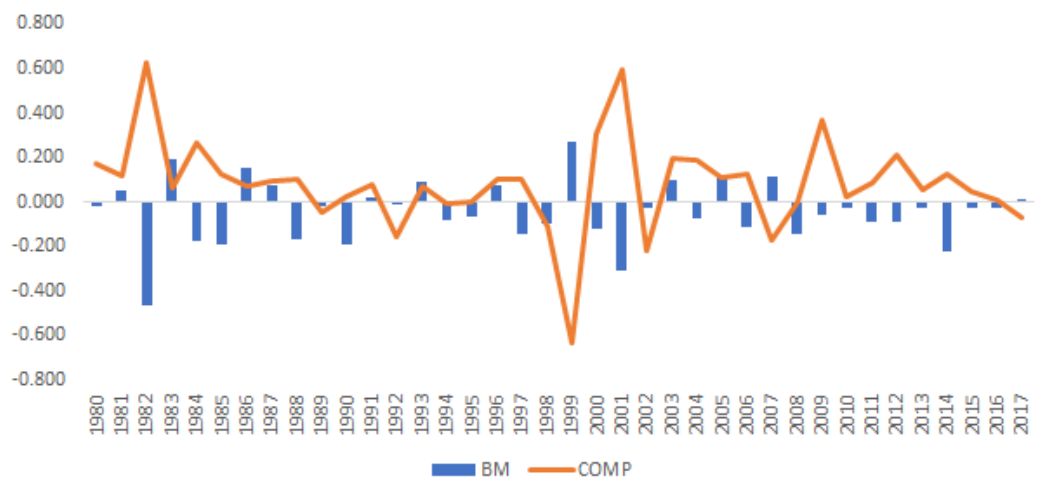




\section{Table 1. Descriptive Statistics}

Panel A presents summary statistics for the sample of 105,380 firm-year observations from 1975 to 2016. Panels B and C present market value of firms and number of firms by RankDiff groups summed across preand post-1990. Refer to Appendix A for variables definitions.

\begin{tabular}{lcccccc}
\hline Panel A: Summary Statistics & & & & & \\
\hline Variables & Mean & Std Dev & P25 & Median & P75 & N \\
\hline$B / M$ & 0.67 & 0.86 & 0.29 & 0.52 & 0.86 & 105,380 \\
$R / M$ & 0.27 & 0.99 & 0.05 & 0.25 & 0.52 & 105,380 \\
$E / P$ & 0.04 & 0.33 & 0.02 & 0.05 & 0.09 & 105,380 \\
$C / P$ & 0.12 & 0.25 & 0.03 & 0.09 & 0.17 & 105,380 \\
$S / P$ & 2.13 & 3.80 & 0.49 & 1.12 & 2.39 & 105,380 \\
EBITDA $/ E V$ & 0.13 & 0.64 & 0.07 & 0.12 & 0.18 & 105,380 \\
SHRYLD & -0.03 & 0.31 & -0.06 & 0.00 & 0.05 & 105,380 \\
COMP & 247.50 & 106.55 & 167.00 & 252.00 & 328.00 & 105,380 \\
$M V E(b n)$ & 2.70 & 14.65 & 0.07 & 0.26 & 1.07 & 105,380 \\
AT (bn) & 2.78 & 15.92 & 0.07 & 0.27 & 1.18 & 105,380 \\
MM & 0.07 & 0.66 & -0.25 & -0.03 & 0.24 & 105,380 \\
RankDiff (B/M vs. $R / M)$ & 0.90 & 1.01 & 0.00 & 1.00 & 1.00 & 105,380 \\
RankDiff $(B / M$ vs. $C O M P)$ & 1.05 & 1.04 & 0.00 & 1.00 & 2.00 & 105,380 \\
CorrDiff $(B / M$ vs. $R / M)$ & 0.001 & 0.396 & -0.230 & -0.003 & 0.228 & 105,380 \\
CorrDiff $(B / M$ vs. $C O M P)$ & 0.002 & 0.402 & -0.237 & -0.002 & 0.238 & 105,380 \\
\hline
\end{tabular}


Panel B: Market Value and Number of Firms by Ranking Difference, B/M vs. R/M

\begin{tabular}{|c|c|c|c|c|c|c|c|c|c|}
\hline \multicolumn{5}{|c|}{ Pre-1990 (B/M vs. R/M) } & \multicolumn{5}{|c|}{ Post-1990 (B/M vs. R/M) } \\
\hline RankDif & MVE (bn) & $\%$ & No. of Firms & $\%$ & RankDiff & ff MVE (bn) & $\%$ & No. of Firms & $\%$ \\
\hline 0 & 7,442 & $33.6 \%$ & 18,901 & $49.2 \%$ & 0 & 68,368 & $26.0 \%$ & 25,900 & $38.7 \%$ \\
\hline 1 & 10,625 & $48.0 \%$ & 14,454 & $37.6 \%$ & 1 & 110,865 & $42.2 \%$ & 23,864 & $35.6 \%$ \\
\hline 2 & 3,420 & $15.4 \%$ & 3,562 & $9.3 \%$ & 2 & 54,275 & $20.7 \%$ & 10,135 & $15.1 \%$ \\
\hline 3 & 553 & $2.5 \%$ & 1,009 & $2.6 \%$ & 3 & 23,328 & $8.9 \%$ & 4,478 & $6.7 \%$ \\
\hline 4 & 114 & $0.5 \%$ & 470 & $1.2 \%$ & 4 & 5,640 & $2.1 \%$ & 2,607 & $3.9 \%$ \\
\hline
\end{tabular}

Panel C: Market Value and Number of Firms, B/M vs. COMP

\begin{tabular}{|c|c|c|c|c|c|c|c|c|c|}
\hline \multicolumn{5}{|c|}{ Pre-1990 (B/M vs. COMP) } & \multicolumn{5}{|c|}{ Post-1990 (B/M vs. COMP) } \\
\hline RankDif & MVE (bn) & $\%$ & No. of Firms & $\%$ & RankDifl & I MVE (bn) & $\%$ & No. of Firms & $\%$ \\
\hline 0 & 6,748 & $30.5 \%$ & 14,610 & $38.1 \%$ & 0 & 62,582 & $23.8 \%$ & 23,299 & $34.8 \%$ \\
\hline 1 & 8,679 & $39.2 \%$ & 14,057 & $36.6 \%$ & 1 & 98,017 & $37.3 \%$ & 23,604 & $35.2 \%$ \\
\hline 2 & 5,355 & $24.2 \%$ & 6,805 & $17.7 \%$ & 2 & 64,903 & $24.7 \%$ & 12,413 & $18.5 \%$ \\
\hline 3 & 1,210 & $5.5 \%$ & 2,245 & $5.8 \%$ & 3 & 30,404 & $11.6 \%$ & 5,563 & $8.3 \%$ \\
\hline 4 & 162 & $0.7 \%$ & 679 & $1.8 \%$ & 4 & 6,568 & $2.5 \%$ & 2,105 & $3.1 \%$ \\
\hline
\end{tabular}




\section{Table 2. Correlations}

Panel A presents correlations among various valuation multiples, where the lower (upper) triangle shows Pearson (Spearman rank) correlations. Panel B reports correlations of book-to-market with other valuation multiples across pre-and post-1990. Refer to Appendix A for variables definitions.

\begin{tabular}{lcccccccc}
\hline \multicolumn{7}{l}{ Panel A: Correlations among various valuation multiples } \\
\hline Variables & $\mathrm{B} / \mathrm{M}$ & $\mathrm{R} / \mathrm{M}$ & $\mathrm{COMP}$ & $\mathrm{E} / \mathrm{P}$ & $\mathrm{C} / \mathrm{P}$ & $\mathrm{S} / \mathrm{P}$ & $\mathrm{EBITDA} / \mathrm{EV}$ & $\mathrm{SHRYLD}$ \\
\hline$B / M$ & & 0.6653 & 0.5024 & 0.4395 & 0.4812 & 0.6859 & 0.5782 & 0.1501 \\
$R / M$ & 0.4151 & & 0.5335 & 0.5554 & 0.4591 & 0.5835 & 0.6080 & 0.2747 \\
$C O M P$ & 0.3148 & 0.2744 & & 0.6311 & 0.7401 & 0.6543 & 0.7686 & 0.5511 \\
$E / P$ & 0.1714 & 0.2700 & 0.1918 & & 0.4799 & 0.4656 & 0.7534 & 0.2111 \\
$C / P$ & 0.4737 & 0.1449 & 0.4523 & 0.1088 & & 0.5009 & 0.6443 & 0.3635 \\
$S / P$ & 0.4909 & 0.2205 & 0.3526 & 0.0555 & 0.3523 & & 0.6765 & 0.2041 \\
$E B I T D A / E V$ & 0.0670 & 0.0641 & 0.1534 & 0.0508 & 0.0843 & 0.0742 & & 0.2850 \\
$S H R Y L D$ & 0.0170 & 0.0780 & 0.2557 & 0.0663 & 0.1327 & 0.0154 & 0.0173 & \\
\hline
\end{tabular}

\begin{tabular}{cccccccc}
\hline \multicolumn{6}{c}{ Panel B: Correlations of Book-to-Market with other Multiples by Period } \\
\hline Period & R/M & COMP & E/P & C/P & S/P & EBITDA/EV & SHRYLD \\
\hline Full & 0.4151 & 0.3148 & 0.1714 & 0.4737 & 0.4909 & 0.0670 & 0.0170 \\
Pre-1990 & 0.7935 & 0.4254 & 0.1998 & 0.3796 & 0.5614 & 0.0899 & 0.0576 \\
Post-1990 & 0.3075 & 0.2728 & 0.1548 & 0.5121 & 0.4410 & 0.0437 & 0.0007 \\
\hline
\end{tabular}




\section{Table 3. Annual Portfolio Returns by B/M, R/M, and COMP}

This table presents equal-weighted market-adjusted returns for portfolios sorted by book-to-market, retained earnings-to-market, and the composite score. Returns are computed annually based on portfolios formed at the end of each June. Refer to Appendix A for variables definitions.

\begin{tabular}{cccc}
\hline Quintile & $\mathrm{B} / \mathrm{M}$ & $\mathrm{R} / \mathrm{M}$ & $\mathrm{COMP}$ \\
\hline 1 (Low) & $-4.29 \%$ & $-4.30 \%$ & $-6.96 \%$ \\
2 & $-0.02 \%$ & $-0.19 \%$ & $-1.20 \%$ \\
3 & $1.06 \%$ & $1.86 \%$ & $0.52 \%$ \\
4 & $1.19 \%$ & $1.89 \%$ & $1.93 \%$ \\
5 (High) & $1.42 \%$ & $2.14 \%$ & $3.58 \%$ \\
5 - 1 (High - Low) & $6.75 \%$ & $7.80 \%$ & $11.78 \%$ \\
(t-statistics) & $(13.17)$ & $(14.21)$ & $(21.55)$ \\
\hline
\end{tabular}




\section{Table 4. Relation between Ranking Difference and Return Predictability}

This table reports estimates from the following Fama-MacBeth regressions: $\operatorname{Ret}_{i, t+1}=\alpha+\beta_{1}$ Valuation $_{\text {Rank }}, t+$ $\beta_{2}$ RankDiff $_{i, t}+\beta_{3}$ Valuation Rank $_{i, t} \times$ RankDiff $_{i, t}+$ Controls. Ret $_{i, t+1}$ refers to firm $i$ 's future 1-year returns. Valuation Rank refers to firm's quintile ranking based on $\mathrm{B} / \mathrm{M}, \mathrm{R} / \mathrm{M}$, and COMP. RankDiff is calculated by taking the absolute difference between firm $i$ 's book-to-market quintile ranking and $\mathrm{R} / \mathrm{M}$ (or COMP) quintile ranking at year $t$. $M V E$ represents firm's market value of equity at December of year t-1. MM represents firm's past 12-month returns prior to portfolio formation. Standard errors are Newey-West adjusted by three lags to control for time-series autocorrelation.

\begin{tabular}{|c|c|c|c|c|c|c|}
\hline \multirow[t]{2}{*}{ Dependent Variable: } & \multicolumn{3}{|c|}{$\mathrm{B} / \mathrm{M}$ vs. $\mathrm{R} / \mathrm{M}$} & \multicolumn{3}{|c|}{ B/M vs. COMP } \\
\hline & (1) & $(2)$ & (3) & $(4)$ & $(5)$ & $(6)$ \\
\hline B/MRank & $\begin{array}{c}0.0217^{* * *} \\
(3.82)\end{array}$ & & $\begin{array}{c}0.0066 \\
(1.50)\end{array}$ & $\begin{array}{c}0.0292^{* * *} \\
\quad(4.10)\end{array}$ & & $\begin{array}{c}0.0024 \\
(0.80)\end{array}$ \\
\hline B/MRankXRankDiff & $\begin{array}{c}-0.0110^{* * *} \\
(-3.86)\end{array}$ & & & $\begin{array}{c}-0.0146^{* * *} \\
(-4.77)\end{array}$ & & \\
\hline RMRank & & $\begin{array}{c}0.0211^{* * *} \\
(3.68)\end{array}$ & $\begin{array}{c}0.0131^{* * *} \\
(2.97)\end{array}$ & & & \\
\hline RMRankXRankDiff & & $\begin{array}{c}-0.0046^{*} \\
(-1.77)\end{array}$ & & & & \\
\hline COMPRank & & & & & $\begin{array}{c}0.0279^{* * *} \\
(3.97)\end{array}$ & $\begin{array}{c}0.0239^{* * *} \\
(4.52)\end{array}$ \\
\hline COMPRankXRankDiff & & & & & $\begin{array}{c}-0.0033 \\
(-1.52)\end{array}$ & \\
\hline RankDiff & $\begin{array}{c}0.0416^{* * *} \\
(3.83)\end{array}$ & $\begin{array}{c}0.0199^{* *} \\
(2.20)\end{array}$ & & $\begin{array}{c}0.0491^{* * * *} \\
(4.66)\end{array}$ & $\begin{array}{c}0.0131^{*} \\
(1.69)\end{array}$ & \\
\hline$M V E$ & $\begin{array}{c}-0.0022 \\
(-1.04)\end{array}$ & $\begin{array}{c}-0.0024 \\
(-1.10)\end{array}$ & $\begin{array}{c}-0.0022 \\
(-0.97)\end{array}$ & $\begin{array}{c}-0.0022 \\
(-1.03)\end{array}$ & $\begin{array}{c}-0.0025 \\
(-1.17)\end{array}$ & $\begin{array}{c}-0.0025 \\
(-1.14)\end{array}$ \\
\hline$M M$ & $\begin{array}{c}0.0396^{* *} \\
(2.36)\end{array}$ & $\begin{array}{c}0.0388^{* *} \\
(2.36)\end{array}$ & $\begin{array}{c}0.0379^{* *} \\
(2.32)\end{array}$ & $\begin{array}{c}0.0367^{* *} \\
(2.33)\end{array}$ & $\begin{array}{c}0.0338^{* *} \\
(2.25)\end{array}$ & $\begin{array}{c}0.0331^{* *} \\
(2.20)\end{array}$ \\
\hline $\mathrm{N}$ & 105,380 & 105,380 & 105,380 & 105,380 & 105,380 & 105,380 \\
\hline R-sq & 0.034 & 0.035 & 0.034 & 0.039 & 0.044 & 0.043 \\
\hline
\end{tabular}




\section{Table 5. Relation Between Ranking Difference and Portfolio Returns}

Table 5 reports estimates from the following regression: $\operatorname{Ret}_{i, m, t}=\beta_{1} \operatorname{RetDiff}_{i, m, t}+\beta_{2} \operatorname{RankDiff}_{i, t}+\beta_{3} \operatorname{RankDiff}_{i, t} \times$ $\operatorname{RetDiff}_{i, m, t}$. Ret ${ }_{i, m, t}$ refers to firm $i$ 's monthly returns in month $m$ at year $t$. RetDiff $f_{i, m, t}$ is calculated by taking the difference between firm's corresponding monthly book-to-market portfolio returns and monthly retained earnings-to-market (composite) portfolio returns. RankDiff is calculated by taking the absolute difference between firm $i$ 's book-to-market quintile ranking and retained earnings-to-market (composite) quintile rankings at year $t$. Columns (1), (2), (3) use RetDiff and RankDiff computed from retained earnings-to-market, and (4), (5), (6) from the composite signal. The parentheses contain t-statistics based on standard errors clustered by firm and year. *, **, *** indicate statistical significance at less than $10 \%, 5 \%$, and $1 \%$, respectively. Refer to Appendix A for variables definitions.

\begin{tabular}{|c|c|c|c|c|c|c|}
\hline Dependent Variable: & $\begin{array}{r}\operatorname{Ret}_{i, m, t} \\
(1)\end{array}$ & $\begin{array}{l}\mathrm{B} / \mathrm{M} \text { vs. } \mathrm{R} / \mathrm{M} \\
\text { (2) }\end{array}$ & (3) & \multicolumn{3}{|c|}{$\begin{array}{c}\mathrm{B} / \mathrm{M} \text { vs. } \mathrm{COMP} \\
\text { (5) }\end{array}$} \\
\hline RetDiff & $\begin{array}{c}-0.5465^{* * *} \\
(-4.09)\end{array}$ & $\begin{array}{c}-0.5396^{* * *} \\
(-4.08)\end{array}$ & $\begin{array}{c}-0.5371^{* * *} \\
(-4.09)\end{array}$ & $\begin{array}{c}-0.5329^{* * *} \\
(-4.30)\end{array}$ & $\begin{array}{c}-0.5277^{* * *} \\
(-4.28)\end{array}$ & $\begin{array}{c}-0.5264^{* * *} \\
(-4.29)\end{array}$ \\
\hline & $\begin{array}{c}0.0005^{*} \\
(1.91)\end{array}$ & $\begin{array}{c}0.0016^{* * *} \\
(6.94)\end{array}$ & $\begin{array}{c}0.0015^{* * *} \\
(6.85)\end{array}$ & $\begin{array}{c}0.0005^{* *} \\
(2.48)\end{array}$ & $\begin{array}{c}0.0009^{* * *} \\
(5.71)\end{array}$ & $\begin{array}{c}0.0008^{* * *} \\
(5.64)\end{array}$ \\
\hline RetDiff X RankDiff & $\begin{array}{c}0.1857^{* * *} \\
(4.28)\end{array}$ & $\begin{array}{c}0.1835^{* * *} \\
(4.22)\end{array}$ & $\begin{array}{c}0.1823^{* * *} \\
(4.26)\end{array}$ & $\begin{array}{c}0.1392^{* * *} \\
(3.93)\end{array}$ & $\begin{array}{c}0.1389^{* * *} \\
(3.84)\end{array}$ & $\begin{array}{c}0.1383^{* * *} \\
(3.87)\end{array}$ \\
\hline$M V E$ & & & $\begin{array}{c}-0.0001^{* * *} \\
(-3.33)\end{array}$ & & & $\begin{array}{c}-0.0001^{* * *} \\
(-3.29)\end{array}$ \\
\hline$M M$ & & & $\begin{array}{c}-0.0030^{* *} \\
(-2.30)\end{array}$ & & & $\begin{array}{c}-0.0032^{* *} \\
(-2.51)\end{array}$ \\
\hline $\mathrm{N}$ & $1,262,598$ & $1,262,598$ & $1,262,598$ & $1,262,598$ & $1,262,598$ & $1,262,598$ \\
\hline R-sq & 0.007 & 0.022 & 0.023 & 0.009 & 0.024 & 0.024 \\
\hline YEAR FE & YES & YES & YES & YES & YES & YES \\
\hline FIRM FE & NO & YES & YES & NO & YES & YES \\
\hline
\end{tabular}




\section{Table 6. Relation Between Ranking Difference and Portfolio Correlations}

Table 6 reports estimates from the following regression: CorrDiff $f_{i, t}=\beta_{1}$ RankDiff $_{i, t}+$ Controls. The parentheses contain t-statistics based on standard errors clustered by firm. *, **, *** indicate statistical significance at less than $10 \%, 5 \%$, and $1 \%$, respectively. Refer to Appendix A for variables definitions.

\begin{tabular}{|c|c|c|c|c|}
\hline \multicolumn{5}{|c|}{ Panel A: Correlation using 12-month returns } \\
\hline \multirow[t]{2}{*}{ Dependent Variable: } & \multicolumn{2}{|c|}{$\begin{array}{l}\text { CorrDiff } f_{i, t} \\
\text { B/M vs. R/M }\end{array}$} & \multicolumn{2}{|c|}{$\mathrm{B} / \mathrm{M}$ vs. COMP } \\
\hline & (1) & $(2)$ & $(3)$ & $(4)$ \\
\hline RankDiff & $\begin{array}{l}0.0216^{* * *} \\
(11.34)\end{array}$ & $\begin{array}{c}0.0212^{* * *} \\
(11.16)\end{array}$ & $\begin{array}{c}0.0059^{* * *} \\
(3.91)\end{array}$ & $\begin{array}{l}0.0057^{* * *} \\
(3.74)\end{array}$ \\
\hline$M V E$ & & $\begin{array}{c}-0.0004^{* * *} \\
(-2.78)\end{array}$ & & $\begin{array}{c}-0.0004^{* * *} \\
(-3.62)\end{array}$ \\
\hline$M M$ & & $\begin{array}{c}-0.0111^{* * *} \\
(-5.80)\end{array}$ & & $\begin{array}{c}-0.0142^{* * *} \\
(-7.76)\end{array}$ \\
\hline YEAR FE & YES & YES & YES & YES \\
\hline FIRM FE & NO & NO & NO & NO \\
\hline $\mathrm{N}$ & 105,380 & 105,380 & 105,380 & 105,380 \\
\hline R-sq & 0.010 & 0.010 & 0.007 & 0.008 \\
\hline
\end{tabular}

Panel B: Correlation using returns of various horizons (12, 6, 3 months)

Dependent Variable: CorrDiff $f_{i, t}$

\begin{tabular}{|c|c|c|c|c|c|c|}
\hline & \multicolumn{3}{|c|}{ BM vs. RM } & \multicolumn{3}{|c|}{$\mathrm{BM}$ vs. COMP } \\
\hline & $\begin{array}{c}12-\mathrm{mo} \\
(1)\end{array}$ & $\begin{array}{c}\text { 6-mo } \\
(2)\end{array}$ & $\begin{array}{c}3-\mathrm{mo} \\
(3)\end{array}$ & $\begin{array}{c}12-\mathrm{mo} \\
(4)\end{array}$ & $\begin{array}{c}\text { 6-mo } \\
(5)\end{array}$ & $\begin{array}{c}3-\mathrm{mo} \\
(6)\end{array}$ \\
\hline RankDiff & $\begin{array}{c}0.0212^{* * *} \\
(11.16)\end{array}$ & $\begin{array}{c}0.0226^{* * *} \\
(9.79)\end{array}$ & $\begin{array}{c}0.0255^{* * *} \\
(7.76)\end{array}$ & $\begin{array}{c}0.0057^{* * *} \\
(3.74)\end{array}$ & $\begin{array}{c}0.0075^{* * *} \\
(3.76)\end{array}$ & $\begin{array}{c}0.0110^{* * *} \\
(3.76)\end{array}$ \\
\hline Size & $\begin{array}{c}-0.0004^{* * *} \\
(-2.78)\end{array}$ & $\begin{array}{c}-0.0003^{*} \\
(-1.69)\end{array}$ & $\begin{array}{c}-0.0000 \\
(-0.06)\end{array}$ & $\begin{array}{c}-0.0004^{* * *} \\
(-3.62)\end{array}$ & $\begin{array}{c}-0.0003^{* *} \\
(-2.26)\end{array}$ & $\begin{array}{c}-0.0005^{* *} \\
(-2.32)\end{array}$ \\
\hline$M M$ & $\begin{array}{c}-0.0111 \text { *** } \\
(-5.80)\end{array}$ & $\begin{array}{c}-0.0153^{* * *} \\
(-5.95)\end{array}$ & $\begin{array}{c}-0.0258^{* * *} \\
(-7.01)\end{array}$ & $\begin{array}{c}-0.0142^{* * *} \\
(-7.76)\end{array}$ & $\begin{array}{c}-0.0159^{* * *} \\
(-6.00)\end{array}$ & $\begin{array}{c}-0.0153^{* * *} \\
(-4.13)\end{array}$ \\
\hline Year FE & YES & YES & YES & YES & YES & YES \\
\hline Firm FE & NO & NO & NO & NO & $\mathrm{NO}$ & $\mathrm{NO}$ \\
\hline $\mathrm{N}$ & 105,380 & 105,380 & 105,376 & 105,380 & 105,380 & 105,376 \\
\hline R-sq & 0.010 & 0.007 & 0.006 & 0.008 & 0.007 & 0.004 \\
\hline
\end{tabular}




\section{Appendix A. Variables Definitions}

\begin{tabular}{|c|c|}
\hline$B / M$ & $\begin{array}{l}\text { Book value of equity }(c e q) \text { divided by market value of equity at the } \\
\text { end of December of year } t-1 \text {. }\end{array}$ \\
\hline$B / M \operatorname{Rank}$ & Quintile ranking of a firm on a given year based on book-to-market. \\
\hline$R / P$ & Retained earnings (re-acominc) divided by market value of equity. \\
\hline$E / P$ & Net income $(n i)$ divided by market value of equity. \\
\hline$C / P$ & Cash flow (oancf) divided by market value of equity. \\
\hline$S / P$ & Sales (sale) divided by market value of equity. \\
\hline$E B I T D A / E V$ & $\begin{array}{l}\text { Earnings before interest, tax, depreciation, and amortization ex- } \\
\text { penses }(e b i t d a) \text { divided by enterprise value (long-term debt }(d t)+ \\
\text { market value of equity - cash }(c h)) \text {. }\end{array}$ \\
\hline$S H R Y L D$ & $\begin{array}{l}\text { Shareholder yield, defined by sum of dividend }(d v) \text {, net amount re- } \\
\text { purchased }(\text { prstkc - sstk), and net debt repayment }(\text { dltr }- \text { dltis }) \text {, } \\
\text { divided by the market value of equity. }\end{array}$ \\
\hline$C O M P$ & $\begin{array}{l}\text { Composite score, which is the sum of percentile rankings sorted by } \\
\mathrm{E} / \mathrm{P}, \mathrm{C} / \mathrm{P}, \mathrm{S} / \mathrm{P}, \mathrm{EBITDA} / \mathrm{EV} \text {, and shareholder yield. }\end{array}$ \\
\hline COMP Rank & $\begin{array}{l}\text { Quintile ranking of a firm on a given year based on the composite } \\
\text { score. }\end{array}$ \\
\hline Ret & Firm's market-adjusted monthly returns. \\
\hline RetDiff & $\begin{array}{l}\text { Difference between a firm's corresponding monthly book-to-market } \\
\text { portfolio returns and composite portfolio returns. }\end{array}$ \\
\hline RankDiff & $\begin{array}{l}\text { Absolute difference between } B / M \operatorname{Rank} \text { and } R / M \text { Rank or Comp } \\
\text { Rank. }\end{array}$ \\
\hline CorrDiff & $\begin{array}{l}\text { Correlation between a firm's monthly returns and its corresponding } \\
\text { book-to-market portfolio returns, minus the correlation between a } \\
\text { firm's monthly returns and its corresponding retained earnings-to- } \\
\text { market (or composite) portfolio returns. Correlations are measured } \\
\text { over a 12-month horizon. }\end{array}$ \\
\hline$M V E$ & Market value of equity of a firm at December of year $t-1$. \\
\hline$M M$ & $\begin{array}{l}\text { Cumulative past } 12 \text {-month stock returns prior to portfolio forma- } \\
\text { tion. }\end{array}$ \\
\hline
\end{tabular}




\section{Bibliography}

[1] Ray Ball, Joseph Gerakos, Juhani Linnainmaa, and Valeri Nikolaev. Earings, Retained Earnings, and Book-to-Market in the Cross Section of Expected Returns. Journal of Financial Economics, forthcoming, 2018.

[2] Nicholas Barberis and Andrei Shleifer. Style investing. Journal of Financial Economics, 68(2):161-199, 2003.

[3] Nicholas Barberis, Andrei Shleifer, and Jeffrey Wurgler. Comovement. Journal of Financial Economics, 75(2):283-317, 2005.

[4] Mary E. Barth, Ken Li, and Charles McClure. Evolution in value relevance of accounting information. Ssrn, 2018.

[5] Sushil Bikhchandani, David Hirshleifer, and Ivo Welch. A theory of fads, fashion, custom, and cultural change as informational cascades. Journal of Political Economy, 19(9):155-179, 1992.

[6] Markus K Brunnermeier and Stefan Nagel. Hedge funds and the technology bubble. Journal of Finance, LIX(5):2013-2040, 2004.

[7] John Y. Campbell, Christopher Polk, and Tuomo Vuolteenaho. Growth or glamour? Fundamentals and systematic risk in stock returns. Review of Financial Studies, 23(1):305-344, 2010.

[8] Louis K. C. Chan Chan, Yasushi Hamao, and Josef Laknoishok. Fundamentals and stock returns in Japan. Journal of Finance, 46(5):1739-1764, 1991.

[9] Louis K.C. Chan, Josef Lakonishok, and Theodore Sougiannis. The Stock Market Valuation of Research. Journal of Finance, LVI(6):2431-2456, 2001.

[10] Joshua Coval and Erik Stafford. Asset fire sales (and purchases) in equity markets. Journal of Financial Economics, 86(2):479-512, 2007.

[11] Jeff Cox. Companies set to buy back $\$ 1$ trillion worth of shares this year, and that should keep market afloat, goldman says. CNBC, 2018.

[12] Roger M. Edelen, Ozgur S. Ince, and Gregory B. Kadlec. Institutional investors and stock return anomalies. Journal of Financial Economics, 119(3):472-488, 2016.

[13] Luminita Enache and Anup Srivastava. Should intangible investments be reported separately or commingled with operating expenses? New evidence. Management Science, (June 2018), 2016.

[14] Travis Fairchild. Negative Equity, Veiled Value, and the Erosion of Price-to-Book. O'Shaughnessy Asset Management Research, (April):1-12, 2018.

[15] Eugene F . Fama and Kenneth R. French. The cross-section of expected stock returns. Journal of Finance, 47(2):427-465, 1992. 
[16] Kenneth Froot and Melvyn Teo. Style Investing and Institutional Investors. Journal of Financial and Quantitative Analysis, 43(4):883-906, 2008.

[17] Samuel G. Hanson and Adi Sunderam. The growth and limits of arbitrage: Evidence from short interest. Review of Financial Studies, 27(4):1238-1286, 2014.

[18] Mark Hulbert. Why the traditional way of measuring 'value' stocks may be history. The Wall Street Journal, 2018.

[19] Alon Kumar. Dynamic style preferences of individual investors and stock returns. Journal of Financial and Quantitative Analysis, 44(3):607-640, 2009.

[20] Josef Lakonishok, Andrei Shleifer, and Robert W Vishny. Contrarian investment, extrapolation, and risk. Journal of Finance, 49(5):1541-1578, 1994.

[21] Baruch Lev and Feng Gu. The end of accounting and the path forward for investors and managers. John Wiley \& Sons, Inc. Hoboken, NJ, USA, 2016.

[22] Maureen McNichols, Madhav V. Rajan, and Stefan Reichelstein. Conservatism correction for the market-to-book ratio and Tobin's q. Review of Accounting Studies, 19(4):1393-1435, 2014.

[23] Partha S Mohanram. Separating winners from losers among low book-to-market stocks using financial statement analysis. Review of Accounting Studies, 10(April):133-170, 2005.

[24] Sendhil Mullainathan. Thinking Through Categories. Unpublished working paper, (April):1-25, 2002.

[25] K. V. Peasnell. Some Formal Connections Between Economic Values and Yields and Accounting Numbers. Journal of Business Finance \&f Accounting, 9(3):361-381, 1982.

[26] Stephen Penman. The Articulation of Price-Earnings Ratios and Market-to-Book Ratios and the Evaluation of Growth. Journal of Accounting Research, 34(2):235-259, 1996.

[27] Joseph D. Piotroski and Eric C. So. Identifying expectation errors in value/glamour strategies: A fundamental analysis approach. Review of Financial Studies, 25(9):2841$2875,2012$.

[28] Gabriel A.D. Preinreich. Annual Survey of Economic Theory : The Theory of Monopoly. Econometrica, 6(3):219-441, 1938.

[29] Barr Rosenberg, Kenneth Reid, and Ronald Lanstein. Persuasive evidence of market inefficiency. The Journal of Portfolio Management, 11(3):9-16, 1985.

[30] David S. Scharfstein and Jeremy C. Stein. Herd behavior and investment. American Economic Review, 80(3):465-479, 1990.

[31] William Sharpe. Asset allocation: management style and performance measurement. Journal of Portfolio Management, (18):7-19, 1992. 
[32] Andrei Shleifer and Robert W Vishny. The limits of arbitrage. Journal of Finance, 52(1):35-55, 1997.

[33] Tyler Shumway and Vincent A. Warther. American Finance Association The Delisting Bias in CRSP' s Nasdaq Data and Its Implications for the Size Effect. Journal of Financeournal of Finance, 54(6):2361-2379, 1999.

[34] Douglas J. Skinner and Richard G. Sloan. Earnings surprises, growth expectations, and stock returns: Don't let an earnings torpedo sink your portfolio. Review of Accounting Studies, pages 289-312, 2002.

[35] Sunil Wahal and M. Deniz Yavuz. Style investing, comovement and return predictability. Journal of Financial Economics, 107(1):136-154, 2013.

[36] Lu Zhang. The value premium. Journal of Finance, 60(1):67-103, 2005. 